\title{
Cytotoxic Activity of Crude Extracts as well as of Pure Components from Jatropha Species, Plants Used Extensively in African Traditional Medicine
}

\author{
Olapeju O. Aiyelaagbe, ${ }^{1}$ Amao A. Hamid, ${ }^{2}$ Ernesto Fattorusso, ${ }^{3}$ Orazio Taglialatela-Scafati, ${ }^{3}$ \\ Heinz C. Schröder, ${ }^{4}$ and Werner E. G. Müller ${ }^{4}$ \\ ${ }^{1}$ Department of Chemistry, University of Ibadan, Ibadan 200284, Nigeria \\ ${ }^{2}$ Department of Chemistry, University of Ilorin, Ilorin 24003, Nigeria \\ ${ }^{3}$ Dipartimento di Chimica delle Sostanze Naturali, Università di Napoli Federico II, Via D. Montesano, 49, 80131 Napoli, Italy \\ ${ }^{4}$ Institute for Physiological Chemistry, University Medical Center of the Johannes Gutenberg University Mainz, Duesbergweg 6, \\ 55128 Mainz, Germany
}

Correspondence should be addressed to Olapeju O. Aiyelaagbe, oaiyelaagbe@yahoo.com and

Werner E. G. Müller, wmueller@uni-mainz.de

Received 29 November 2010; Revised 10 February 2011; Accepted 31 March 2011

Copyright (C) 2011 Olapeju O. Aiyelaagbe et al. This is an open access article distributed under the Creative Commons Attribution License, which permits unrestricted use, distribution, and reproduction in any medium, provided the original work is properly cited.

\begin{abstract}
Extracts from Jatropha curcas, a plant used in African traditional medicine for various diseases, were tested for cytotoxic activity. The root extracts strongly reduced cell growth of tumor cells in vitro, a result consistent with the knowledge of the application of these plant extracts in traditional medicine, especially to cure/ameliorate cancer. A selection of pure diterpenoids existing in extracts from Jatropha species and isolated from J. curcas, for example, curcusone C, curcusone D, multidione, 15-epi-4Z-jatrogrossidentadion, 4Z-jatrogrossidentadion, 4E-jatrogrossidentadion, 2-hydroxyisojatrogrossidion, and 2-epi-hydroxyisojatrogrossidion, were likewise tested, and they also showed strong cytotoxic activity. It turned out that these extracts are highly active against L5178y mouse lymphoma cells and HeLa human cervix carcinoma cells, while they cause none or only very low activity against neuronal cell, for example, PC12. These data underscore that extracts from J. curcas or pure secondary metabolites from the plant are promising candidates to be anticancer drug, combined with low neuroactive effects.
\end{abstract}

\section{Introduction}

Jatropha curcas is a multipurpose (both medicinal and biotechnologically important) plant and drought resistant large shrub which is widely cultivated in Africa and Asia for aesthetics as a live fence (Figure 1), as a source for the production of biodiesel and for medicinal purposes (reviewed in [1]). The plant belongs to the genus Jatropha and family Euphorbiaceae, known for their toxic constituents [2]. While the seeds are used for biodiesel production, the root and rootbark are, among the other parts of the plant, of medicinal relevance. The first description of J. curcas was published by von Linné [3] who gave a few years later a more comprehensive description of the genus Jatropha including more species [4] Figures 2(a), 2(d), and 2(e). de Jussieu [5] was the first to describe the medical use of extracts from $J$. curcas as being useful if given orally (tunc ad usus varios usurpato) (Figures 2(b) and 2(f)).

In traditional medicine, this plant has been applied since the earliest times for the cure of various ailments ranging from simple fevers to infectious diseases including sexually transmitted diseases in many African and Asian countries $[6,7]$. The different parts of the plant serve various medicinal uses. The seeds and the seed oil are used as purgative and as a remedy for syphilis. In addition, the oil is used as a substitute for diesel oil and as fuel $[8,9]$. The leaves are applied extensively in West African ethnomedical practice in different forms to cure various ailments like fever, mouth infections, jaundice, guinea worm sores, and joint rheumatism $[10,11]$. The sap (latex) and crushed leaves have also shown antiparasitic activity $[12,13]$. Furthermore, the latex contains compounds displaying antibacterial activity against 


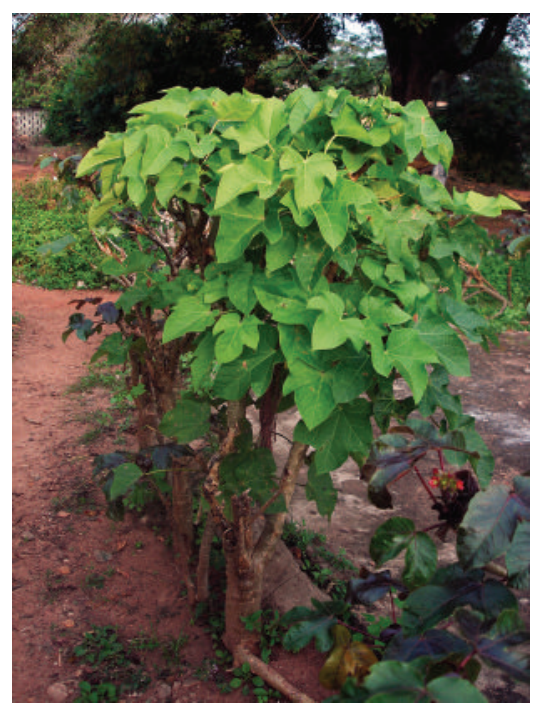

Figure 1: The plant Jatropha curcas, in the local language also termed "lapalapa funfun", is used in the South Western and Middle Belt regions (Nigeria) as live fences. Extracts from the root and rootbarks are used for medicinal applications.

Staphylococcus aureus [14]. Water extract of the branches strongly inhibited HIV- induced cytopathic effects with low cytotoxicity [15]. In addition, the stems contain compounds with strong antimicrobial activities, as proven by studies carried out in Nigeria, and are used as chewing sticks in parts of that country $[16,17]$. Extracts of the stems have been suggested to possess various biological activities including anti-insect, antimicrobial, cytotoxic, anti-inflammatory, and molluscicidal activities [18-25]. The roots of J. curcas are used after decoction as a mouthwash for bleeding gums, toothache, eczema, ringworm, and scabies, and to cure dysentery and venereal diseases, like gonorrhea $[6,11]$.

Previous phytochemical studies on J. curcas resulted in the isolation of many compounds including diterpenes, sterols, flavonoids, alkaloids, and peptides [28-34]. Many of these compounds have shown various biological activities ranging from antimicrobial to anticancer. Curcusone $\mathrm{A}$ and $\mathrm{B}$ isolated from the stems showed anticancer activities while curcusone B, furthermore, effectively suppressed the metastatic processes at nontoxic doses, [35]. It should be stressed, however, that the anticancer activities of curcusone $\mathrm{C}$ and $\mathrm{D}$ have not been reported previously.

In this paper, we report the cytotoxic/cytostatic activities of root extracts and chemical constituents of Jatropha species against certain cancer cell lines along with evidence from traditional healers on the use of this plant in treating different types of cancer. In contrast to the studies published to date, in which pure compounds had been used for the cytotoxicity studies, for example, curcin [36], we analyzed extracts from the plant J. curcas, similar to those that are used for treatment in traditional medicine in the South West and Middle belt regions of Nigeria. The data show that both the extracts from J. curcas as well as its diterpenes are highly active against tumor cells, L5178y mouse lymphoma cells, and
HeLa human cervix carcinoma cells, combined with a low effect on the neuronal cell line PC12.

\section{Materials and Methods}

2.1. Plant Materials. Whole plants of Jatropha curcas (Euphorbiaceae) were collected from the campus of the University of Ibadan, Ibadan, Nigeria in 2006. The plants were authenticated at the Herbarium of the Forestry Research Institute, Ibadan, Nigeria. (Herbarium Voucher Number: FHI 107674). The roots were separated from the rest of the plant, dried, and ground.

2.2. Extraction of Plant Materials. A known amount of the dried, ground root of J. curcas $(1.0 \mathrm{~kg})$ was extracted with n-hexane, ethyl acetate, and methanol to give the respective crude extracts which were concentrated in vacuo. The yields of the extracts were as follows: hexane $10.5 \mathrm{~g}$, ethyl acetate $11.2 \mathrm{~g}$, and methanol $42.3 \mathrm{~g}$.

\subsection{Fractionation of the Extracts and Isolation of the Pure} Compounds. Based on the results of the in-vitro cytotoxicity assay of the extracts, the hexane and ethyl acetate extracts J. curcas were subjected to fractionation by column chromatography. The fractions obtained were subjected to further assays before they were purified by HPLC to obtain the pure compounds. Details of the procedures and characterisation of the compounds have been reported [37]. Fourteen compounds were isolated from the extracts, and some of these compounds had been isolated from Jatropha podagrica and Jatropha multifida (Euphorbiaceae), medicinal plants closely related to J. curcas and which also grows in Nigeria [21, 22, 38, 39].

2.4. Confirmation from the Herbalists on the Efficacy of J. curcas as Anticancer Agents. Two traditional healers and one traditional pediatric pharmacist (herbal seller) were thoroughly interviewed to collect more detailed information on the uses and efficacies of the plant in traditional medicine. The interviews were conducted orally in the vernacular of the people, and the responses were transcribed on paper and subsequently translated by an anthropologist for accuracy. They gave useful information on the different applications involving J. curcas to treat various diseases including cancer (Figures 2 and 3 ).

2.5. Determination of Cytotoxic Activity. The extracts obtained were subjected to an in-vitro cytotoxicity assay applying the MTT [3-(4,5-dimethylthiazol-2-yl)-2,5-diphenyl tetrazolium bromide] (Sigma-Aldrich, Taufkirchen; Germany) method [39-41]. Three different cell lines were routinely used for activity testing: L5178y mouse lymphoma cells [42], PC12 rat adrenal medulla pheochromocytoma cells [43], and also HeLa human cervix carcinoma cells [44]. The cells were grown in RPMI 1640 medium (Gibco BRL, Eggenstein; Germany), supplemented with $10 \mathrm{mM}$ Hepes [hydroxyethylpiperazineethane-sulfonic acid], 10\% fetal calf serum (FCS) (PAA, Cölbe, Germany) for L5178y and HeLa cells, or 5\% 


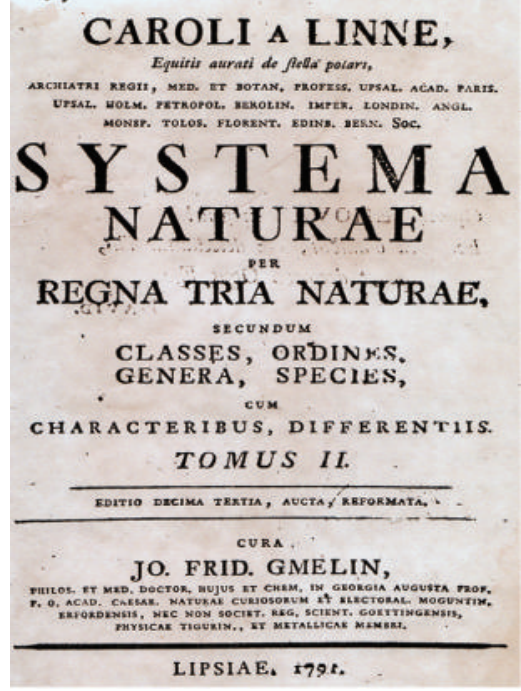

(a)

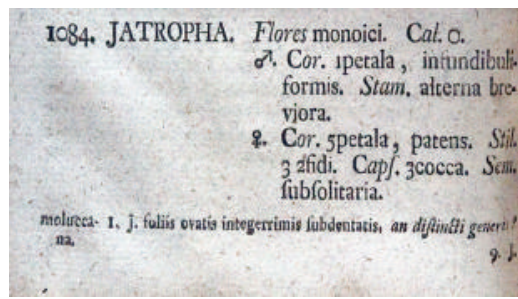

(d)

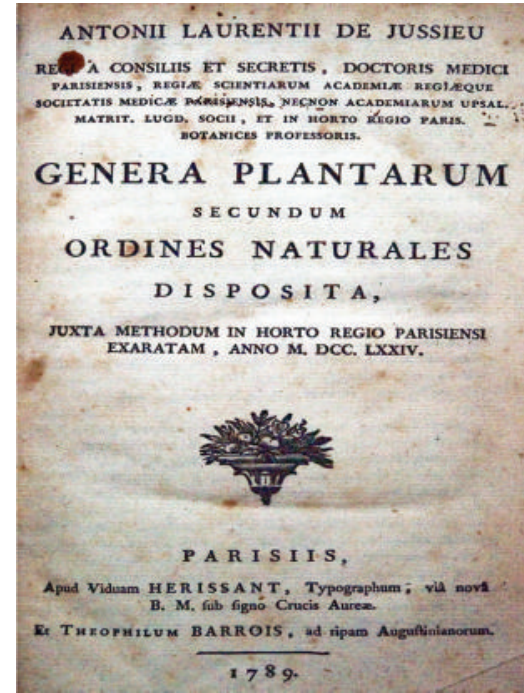

(b)

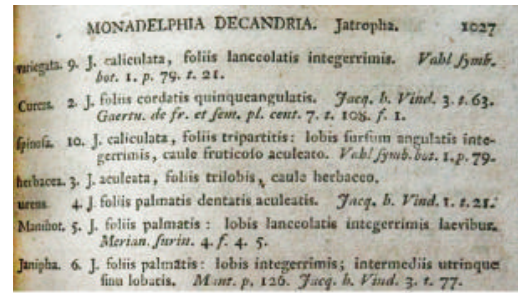

(e)
5) Egbo lapalapa funfun wulo pupe fun aariun jejere. Ao ge kack kectoe $E$, Eg ao pa egbo lapalapa funfun weere topo ma Owa tutu, eru olonla (alane?) karandar ati kankun die. Ao se gbogbo e papo pele Omi toma, ao se jinna daadas. Ake gbe do je. Kidi agbo yioteanle. Ti aba nmu tonbib kutere koptoen laaro ati lale, Ogun yi dara pupo a fun eyikeyi a grun jejere, tkiri Aarun ti agunlagun ati tgbe gbuiru. ati acoon a forie $k 0$ egbo lapalapa funtum Al awoon er eronja $y_{i}$ pape ni Jejere. Jejere. Asi nlo pupo fun fun aerum Yorme. Asi nlo pupifun garin yi nite - Akojopo iwulo lapalaja Funfun ati ogere wa lati owo Alh. Oloogm, lle olalese (ist traditional bealer); Baba ratko Babaisale awo Eegbe tewe togbo mi lis llorm (chairman): at lya lgbefi (lya elewe Omo) ni de Onile, ni oja tuntum. nillu Ilorim, Kuvaros State Neqeria.

(c)

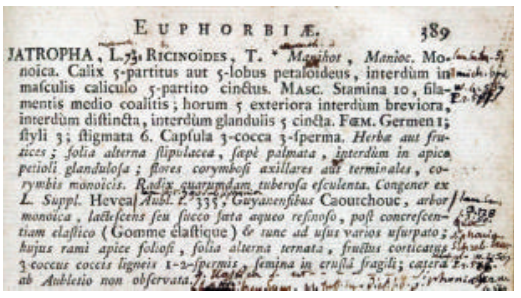

(f)

Figure 2: The first descriptions of J. curcas. (a) Description of the species by von Linné [3]. (b) First description of J. curcas as a medical plant by de Jussieu [5]. (c) Recipe describing J. curcas extracts as antitumor medicine form the traditional healer, Baba Reke. (d, e) Description of the genus Jatropha by von Linné [3, 4], already including 13 species (f).

horse serum for PC12 cells, and 0.1\% gentamycin. All cells were routinely passaged twice weekly. The cells were kept in a humidified atmosphere of $95 \%$ air and $5 \% \mathrm{CO}_{2}$ at $37^{\circ} \mathrm{C}$.

2.6. MTT Assay. To estimate the $\mathrm{EC}_{50}$ values, $\mathrm{L} 5178 \mathrm{y}, \mathrm{PC} 12$, or HeLa cells were incubated for $72 \mathrm{hrs}$ in the presence of different concentrations $(0.1 ; 0.3 ; 1.0 ; 3.0$, and $10.0 \mu \mathrm{g} / \mathrm{mL})$ of the respective extracts. The final volumes in the assays were $200 \mu \mathrm{L}$. All extracts were dissolved in DMSO [dimethyl sulfoxide] (stock solution $10 \mathrm{mg} / \mathrm{mL}$ ) and stored at $-20^{\circ} \mathrm{C}$. The viability of the cells was determined using the MTT colorimetric assay system. The evaluation was performed in 96-well plates at $595 \mathrm{~nm}$ using an ELISA plate reader, after overnight incubation at $37^{\circ} \mathrm{C}$ as described [45].

2.7. Statistics. The $50 \%$ effective concentration $\left(\mathrm{EC}_{50}\right)$, representing that concentration at which the growth rate of the infected cells was reduced by $50 \%$, was estimated by logit regression [26], as described [27]. The means $( \pm S D)$ from 10 separate experiments are given.

\section{Results and Discussion}

3.1. Biomedical Application in Traditional Medicine in the South West/Middle Belt Part of Nigeria. Over 30 different traditional healers and herbal sellers have been interviewed. The interviews were conducted orally in the vernacular of the people, and their responses were transcribed on paper and subsequently translated by an anthropologist for accuracy. The following three representative recipes should be documented here.

The traditional healer Alhaji Oloogun (Figure 3(a)) gave a recipe for the amelioration of skin inflammations (Figure 2(c)) as follows. The roots must be minced and are then extracted together with $1: 100(\mathrm{w} / \mathrm{w})$ Yoruba small sized local pepper with aqueous ethanolic solvent. The slurry is thoroughly mixed $1: 5(\mathrm{v} / \mathrm{v})$ with local black soap. This formulation is then used for everyday bathing in order to treat skin rashes and infections very effectively.

From the second traditional healer, Baba Reke (Figure 3(b)), a recipe was obtained that has frequently been applied to treat sexually transmitted diseases. The J. curcas roots are cut into small pieces and then soaked with an aqueous alcoholic solvent for two to three days. The cleared 


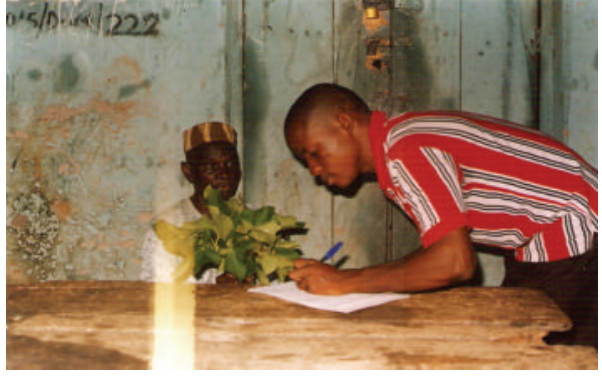

(a)

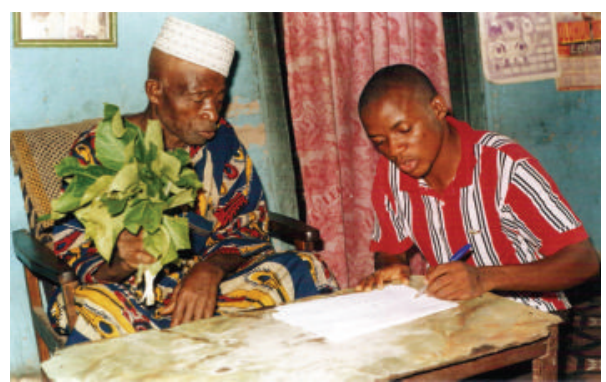

(b)

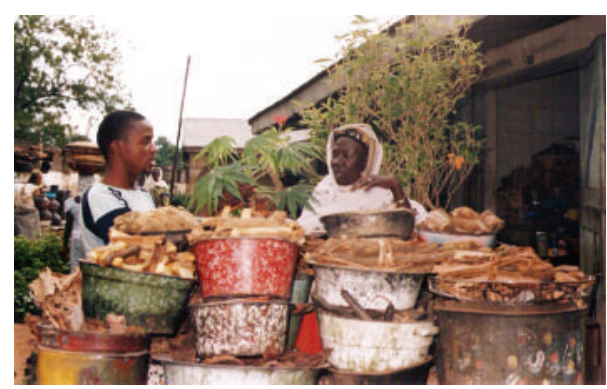

(c)

Figure 3: Medical impact of extracts from J. curcas, as learned from interviews with (a) the traditional healer, Alhaji Oloogun, Ilorin (Kwara state, Nigeria), (b) Baba Reke (Ilorin), and (c) Iya Igbeti, a female Yoruba traditional pediatric pharmacist at the New Market at Ilorin. They described how extracts of this plant, supplemented with black pepper or local black soap (as prepared by the Yoruba tribes of Nigeria), are used as traditional medicine which may also increase appetite and promote secretion, properties which have also been documented in modern medicinal textbooks [50].

extract is used as a drink; small glass cups (about $10 \mathrm{~mL}$ each) of this extract must be drunk twice daily, morning and night. By the experience of this healer, this formulation was successful against any kind of cancer and several types of sexually transmitted diseases, for example, gonorrhea.

Finally, from Iya Igbeti, a female Yoruba traditional pediatric pharmacist (Figure 3(c)), a recipe for the treatment/ amelioration of a broad spectrum of local diseases was obtained. The aqueous extract is again prepared from J. curcas roots, together with the following components; first, with the dried outer parts of the Cassia tora fruits, also termed "eru olounla" or "alamo," and, second, with dried stem bark of guinea corn, Sorghum caudatum, "karandafi" by using small quantity of each $(1: 10 \mathrm{w} / \mathrm{w})$. In order to increase the efficiency of the extraction, the slurry is supplemented with potash $(1: 10 \mathrm{v} / \mathrm{w})$ and natural cotton wool $(1: 10 \mathrm{v} / \mathrm{w})$. The suspension is then boiled at $70^{\circ} \mathrm{C}(60 \mathrm{~min})$ and subsequently heated at $100^{\circ} \mathrm{C}$ for another $60 \mathrm{~min}$ after addition of an equal volume of clean water until it is well cooked. Care should be taken not to allow the extract to rapidly chill. The patients are advised to drink a small glass cup of that formulation twice daily in the morning and night. It was found to be effective against cancer of the intestine, stomach upset, and rheumatism as well as diarrhea.

3.2. Cytostatic Activity of the Extracts. The extracts obtained showed strong cytotoxic activity against the three cell lines with effective inhibition higher than $100 \%$ even at concentrations below $5 \mu \mathrm{g} / \mathrm{mL}$. This concentration had been
TABLE 1: Percentage growth inhibition by $50 \%\left(\mathrm{EC}_{50}\right.$ : effective dose, causing $50 \%$ reduction of cell density during the $72 \mathrm{hrs}$ incubation) by extracts from $J$. curcas roots. The following extracts were tested: hexane extract (JCRBH) and ethyl acetate extract (JCRBEA) as well as methanol extract (JCRBM). The three cells lines L5178y, PC12, and HeLa were used for the experiments.

\begin{tabular}{lccc}
\hline Extracts & \multicolumn{3}{c}{ Tumor cell lines, inhibitory concentration $\mathrm{EC}_{50}(\mu \mathrm{g} / \mathrm{mL})$} \\
& L5178y & PC12 & HeLa \\
\hline JCRBH & $0.82 \pm 0.1$ & $5.7 \pm 0.6$ & $1.7 \pm 0.1$ \\
JCRBEA & $2.2 \pm 0.2$ & $>10.0$ & $2.5 \pm 0.3$ \\
JCRBM & $3.7 \pm 0.3$ & $>10.0$ & $3.1 \pm 0.3$ \\
\hline
\end{tabular}

set as a borderline, below which a compound/extract is termed cytotoxic [46]. The data summarized in Table 1 and in Figure 4(a) show that the hexane extract (JCRBH) possessed highest inhibitory activity. It is remarkable that besides the strong inhibition of L5178y cells, also HeLa cells were affected by the hexane extract. Most cytostatic drugs are much less inhibitory on HeLa cells than on L5178y cells [45]. The extracts prepared with ethyl acetate and methanol were less effective. Remarkable is the weaker effects of all three extracts, especially of those obtained with the more polar solvents, (ethyl acetate and methanol) on PC12 cells. Since this cell line [47] is of neuronal origin it can be expected that also in vivo these extracts might be less/if at all toxic on neuronal tissue. 


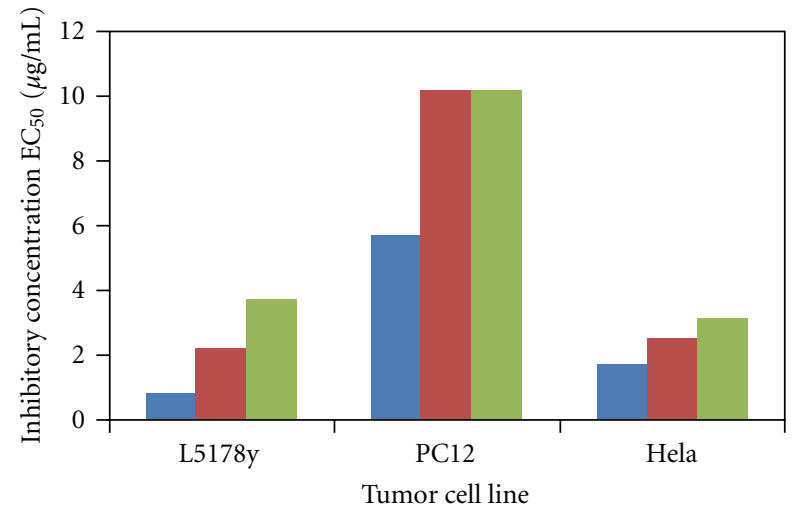

Inhibitory concentration of Jatropha curcas extracts

$$
\begin{aligned}
& \text { - JCRBH } \\
& \text { - JCRBEA } \\
& \text { - JCRBM }
\end{aligned}
$$

(a)

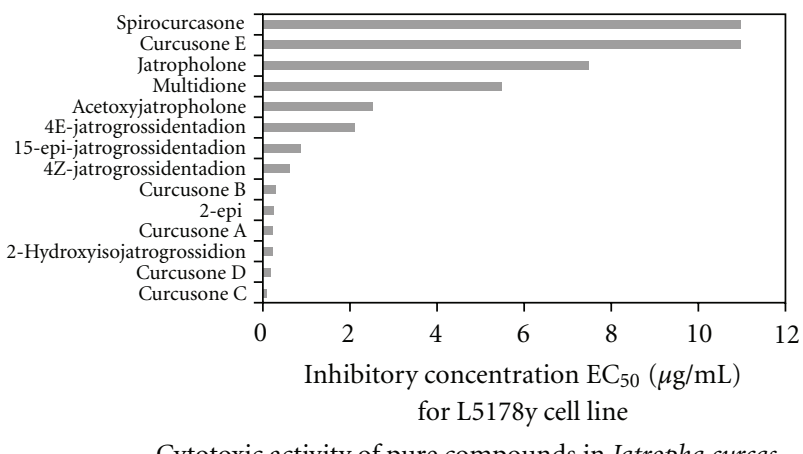

(b)

FIGURE 4: (a) Cytotoxic activity of J. curcas extracts. Further details are given in Table 1. (b) Cytotoxic activity of pure compounds from extracts of $J$. curcas. The pure compounds had been isolated from root extracts as described under Section 2. The means of 10 different experiments $( \pm \mathrm{SD})$ are given as $\mathrm{EC}_{50}$ : effective doses; see also Table 2 for further information.

Previously, some pure compounds have been isolated from organic extracts of J. curcas and other Jatropha species [30, 38, 48, 49]. Here, we isolated fourteen diterpenes by bioassay-guided techniques as described earlier [37]. These compounds were tested for their inhibitory activities on the L5178y cell line (Table 2; Figure 4(b)). Some of the diterpenes showed very strong inhibitory activities. Especially high was the inhibition for curcusone $\mathrm{C}$ with $\mathrm{EC}_{50}$ of $0.08 \mu \mathrm{g} / \mathrm{mL}$. Four curcusones have already earlier been isolated from J. curcas out of which two, namely curcusone A and B, have shown cytotoxic activities [35]. The present study is, however, the first report of the cytotoxic activities for curcusone C and D. The highly potent activities exhibited by curcusone $\mathrm{C}$ and $\mathrm{D}$ suggest that these compounds could be developed further as anticancer drugs. Furthermore, their modes of action have to be investigated; for curcusone $\mathrm{B}$, an antimetastatic activity has already been described [35].

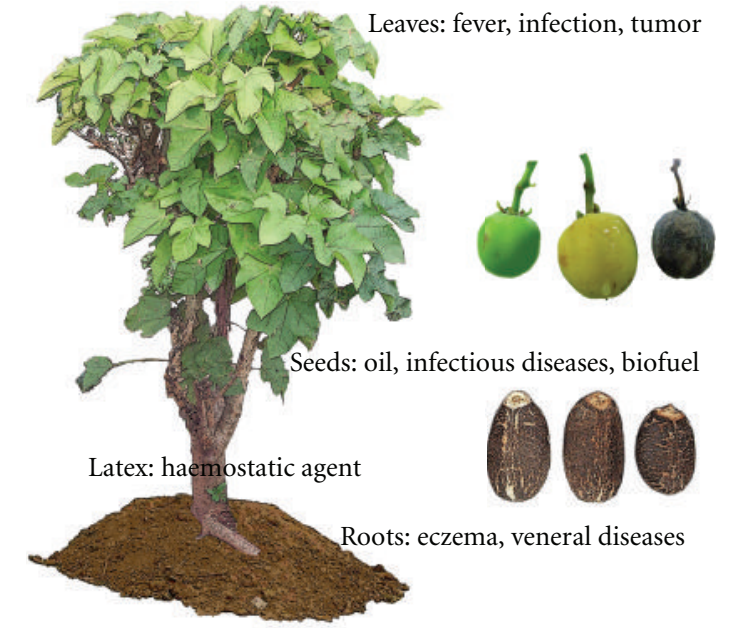

FIGURE 5: Jatropha curcas: from leaves, latex, roots, and seeds different bioactive or commercially important ingredients have been extracted; schematic representation. For details, see text.

TABle 2: Cytotoxic activity of compounds isolated from Jatropha curcas root extracts. The $\mathrm{EC}_{50}$ values are given here; the SD's of the respective values are less than $15 \%$.

\begin{tabular}{lc}
\hline Compounds & $\mathrm{EC}_{50}(\mu \mathrm{g} / \mathrm{mL})$ for L5178y cells \\
\hline Curcusone C & 0.08 \\
Curcusone D & 0.16 \\
2-Hydroxyisojatrogrossidion & 0.20 \\
Curcusone A & 0.21 \\
2-epi-hydroxyisojatrogrossidion & 0.24 \\
Curcusone B & 0.27 \\
4Z-jatrogrossidentadion & 0.60 \\
15-epi-4E-jatrogrossidentadion & 0.85 \\
4E-jatrogrossidentadion & 2.10 \\
Acetoxyjatropholone & 2.50 \\
Multidione & 5.50 \\
Jatropholone & 7.50 \\
Curcusone E & $>10$ \\
Spirocurcasone & $>10$ \\
\hline
\end{tabular}

In conclusion, the present study underscores that the plant J. curcas produces a series of cytostatically active compounds; Figure 5. In view of the present findings that even crude extracts from this plant are highly active, and relatively more active than some of the hitherto known secondary metabolites from this plant, it can be expected that more new compounds with higher cytostatic activity can be isolated in future. However, it should also be considered that the active compounds in the extracts may act synergistically in such a way that the inhibitory effects of the extracts are higher than that of their components. Such a potentiation of individual compounds in extracts, especially from herbs has been discussed before $[50,51]$. 


\section{Acknowledgments}

O.O. Aiyelaagbe is grateful to DAAD (Germany) for a research fellowship to the Johannes Gutenberg-University Mainz (Germany). W. E. G. Müller is a holder of an ERC Advanced Investigator Grant (no. 268476 BIOSILICA). The documentation on the uses of Jatropha curcas was made possible from the interviews conducted with Alhaji Oloogun as well as with Baba Reke who is also the chairman of all the traditional healers in Ilorin (capital of Kwara state in Nigeria). In addition, The authors thank Iya Igbeti (a female Yoruba traditional pediatric pharmacist) for the useful information on uses of Jatropha curcas. They also thank Dr. Aderemi S. Ajala (Georg Foster Fellow (2009) at the Institut fur Ethnologie und Afrikastudien, Universitat Mainz (Germany) for translating the recipe from the Yoruba language to English language. Moreover the authors greatly thank and express appreciation to Professor Edwin L. Cooper for critical reading and useful suggestions on the manuscript.

\section{References}

[1] L. Jimu, I. W. Nyakudya, and C. A. T. Katsvanga, "Establishment and early field performance of Jatropha curcas L at Bindura University Farm, Zimbabwe," Journal of Sustainable Development in Africa, vol. 10, pp. 445-469, 2009.

[2] Y. Hirata, "Toxic substances of Euphorbiaceae," Pure and Applied Chemistry, vol. 41, pp. 175-199, 1975.

[3] C. von Linné, Species Plantarum, Laurenti Salvi, Stockholm, Sweden, 1st edition, 1753.

[4] C. von Linné, Systema naturae, sive regna tria natura systematice proposita per classes, ordines, genera, < species. Tomus II; Pars II, J. F. Gmelin, Lipsiae, Germany, 1791.

[5] A. L. de Jussieu, Genera Plantarum Secundum Ordines Naturales Disposita: juxta methodum in Horto Regio Parisiensi Exaratam, Parisiis, Herissant, 1789.

[6] H. M. Burkill, The Useful Plants of West Tropical Africa, vol. 2, Royal Botanical Gardens, Kew, UK, 1994.

[7] O. O. Thomas, "Re-examination of the antimicrobial activities of Xylopia aethiopica, Carica papaya, Ocimum gratissimum and Jatropha curcas," Fitoterapia, vol. 60, no. 2, pp. 147-155, 1989.

[8] H. J. Berchmans and S. Hirata, "Biodiesel production from crude Jatropha curcas L. seed oil with a high content of free fatty acids," Bioresource Technology, vol. 99, no. 6, pp. 17161721, 2008.

[9] H. Lu, Y. Liu, H. Zhou, Y. Yang, M. Chen, and B. Liang, "Production of biodiesel from Jatropha curcas L. oil," Computers and Chemical Engineering, vol. 33, no. 5, pp. 1091-1096, 2009.

[10] F. R. Irvine, Woody Plants of Ghana: with Special Reference to Their Uses, OUP, London, UK, 2nd edition, 1961.

[11] B. Oliver-Bever, Medicinal Plants in Tropical West Africa, Cambridge University Press, London, UK, 1986.

[12] A. F. Fagbenro-Beyioku, W. A. Oyibo, and B. C. Anuforom, "Disinfectant/antiparasitic activities of Jatropha curcas," East African Medical Journal, vol. 75, no. 9, pp. 508-511, 1998.

[13] O. Osoniyi and F. Onajobi, "Coagulant and anticoagulant activities in Jatropha curcas latex," Journal of Ethnopharmacology, vol. 89, no. 1, pp. 101-105, 2003.

[14] R. Thomas, N. K. Sah, and P. B. Sharma, "Therapeutic biology of Jatropha curcas: a mini review," Current Pharmaceutical Biotechnology, vol. 9, no. 4, pp. 315-324, 2008.
[15] I. T. Matsuse, Y. A. Lim, M. Hattori, M. Correa, and M. P. Gupta, "A search for anti-viral properties in Panamanian medicinal plants. The effects on HIV and its essential enzymes," Journal of Ethnopharmacology, vol. 64, no. 1, pp. 15-22, 1998.

[16] O. O. Igbinosa, E. O. Igbinosa, and O. A. Aiyegoro, "Antimicrobial activity and phytochemical screening of stem bark extracts from Jatropha curcas (Linn)," African Journal of Pharmacy and Pharmacology, vol. 3, no. 2, pp. 058-062, 2009.

[17] J. Kayode and M. A. Omatoyinbo, "Ethnobotanical utilization and conservation of chewing sticks plants species in Ekiti state, Nigeria," Research Journal of Botany, vol. 4, no. 1, pp. 1-9, 2009.

[18] O. O. Aiyelaagbe, E. K. Adesogan, O. Ekundayo, and A. Hassanali, "Antifeedant activity of Jatropha podagrica roots," Fitoterapia, vol. 69, no. 2, pp. 175-176, 1998.

[19] O. O. Aiyelaagbe, E. K. Adesogan, O. Ekundayo, and B. A. Adeniyi, "The antimicrobial activity of roots of Jatropha podagrica (Hook)," Phytotherapy Research, vol. 14, no. 1, pp. 60-62, 2000.

[20] O. O. Aiyelaagbe, B. A. Adeniyi, O. F. Fatunsin, and B. D. Arimah, "In vitro antimicrobial activity and phytochemical analysis of Jatropha curcas roots," International Journal of Pharmacology, vol. 3, no. 1, pp. 106-110, 2007.

[21] B. Das, K. Laxminarayana, M. Krishnaiah, Y. Srinivas, and T. V. Raju, "Multidione, a novel diterpenoid from Jatropha multifida," Tetrahedron Letters, vol. 50, no. 34, pp. 4885-4887, 2009.

[22] B. Das, K. R. Reddy, B. Ravikanth et al., "Multifidone: a novel cytotoxic lathyrane-type diterpene having an unusual six-membered A ring from Jatropha multifida," Bioorganic and Medicinal Chemistry Letters, vol. 19, no. 1, pp. 77-79, 2009.

[23] A. M. Mujumdar and A. V. Misar, "Anti-inflammatory activity of Jatropha curcas roots in mice and rats," Journal of Ethnopharmacology, vol. 90, no. 1, pp. 11-15, 2004.

[24] M. Rug and A. Ruppel, "Toxic activities of the plant Jatropha curcas against intermediate snail hosts and larvae of schistosomes," Tropical Medicine and International Health, vol. 5, no. 6, pp. 423-430, 2000.

[25] R. A. A. Mothana, S. A. A. Abdo, S. Hasson, F. M. N. Althawab, S. A. Z. Alaghbari, and U. Lindequist, "Antimicrobial, antioxidant and cytotoxic activities and phytochemical screening of some yemeni medicinal plants," Evidence-Based Complementary and Alternative Medicine, vol. 7, no. 3, pp. 323-330, 2010.

[26] L. Sachs, Angewandte Statistik, Springer, Berlin, Germany, 1984.

[27] B. E. Weiler, H. C. Schroder, V. Stefanovich et al., "Sulphoevernan, a polyanionic polysaccharide, and the narcissus lectin potently inhibit human immunodeficiency virus infection by binding to viral envelope protein," Journal of General Virology, vol. 71, no. 9, pp. 1957-1963, 1990.

[28] S. M. Khafagy, Y. A. Mohamed, N. A. Abdel Salam, and Z. F. Mahmoud, "Phytochemical study of Jatropha curcas," Planta Medica, vol. 31, no. 3, pp. 274-277, 1977.

[29] A. J. J. Van Den Berg, S. F. A. J. Horsten, J. J. Kettenes-Van Den Bosch et al., "Curcacycline A-a novel cyclic octapeptide isolated from the latex of Jatropha curcas L," FEBS Letters, vol. 358, no. 3, pp. 215-218, 1995.

[30] W. Naengchomnong, Y. Thebtaranonth, P. Wiriyachitra, K. T. Okamoto, and J. Clardy, "Isolation and structure determination of four novel diterpenes from jatropha curcus," Tetrahedron Letters, vol. 27, no. 22, pp. 2439-2442, 1986.

[31] C. Auvin, C. Baraguey, A. Blond, F. Lezenven, J. L. Pousset, and B. Bodo, "Curcacycline B, a cyclic nonapeptide from 
Jatropha curcas enhancing rotamase activity of cyclophilin," Tetrahedron Letters, vol. 38, no. 16, pp. 2845-2848, 1997.

[32] R. Staubmann, M. Schubert-Zsilavecz, A. Hiermann, and T. Kartnig, "A complex of 5-hydroxypyrrolidin-2-one and pyrimidine-2,4-dione isolated from Jatropha curcas," Phytochemistry, vol. 50, no. 2, pp. 337-338, 1999.

[33] N. Ravindranath, M. R. Reddy, C. Ramesh et al., "New lathyrane and podocarpane diterpenoids from Jatropha curcas," Chemical and Pharmaceutical Bulletin, vol. 52, no. 5, pp. 608611, 2004.

[34] P. Manpong, S. Douglas, P. L. Douglas, S. Pongamphai, and W. Teppaitoon, "Preliminary investigation of gallic acid extraction from Jatropha curcas Linn. leaves using supercritical carbon dioxide with methanol co-solvent," Journal of Food Process Engineering. In press.

[35] S. Muangman, M. Thippornwong, and R. Tohtong, "Antimetastatic effects of curcusone B, a diterpene from Jatropha curcas," In Vivo, vol. 19, no. 1, pp. 265-268, 2005.

[36] J. Lin, F. Yan, L. Tang, and F. Chen, "Antitumor effects of curcin from seeds of Jatropha curcas," Acta Pharmacologica Sinica, vol. 24, no. 3, pp. 241-246, 2003.

[37] G. Chianese, E. Fattorusso, O. O. Aiyelaagbe et al., "Spirocurcasone, a diterpenoid with a novel carbon skeleton from Jatropha curcas," Organic Letters, vol. 13, no. 2, pp. 316-319, 2011.

[38] O. O. Aiyelaagbe, J. B. Gloer, E. K. Adesogan, and O. Ekundayo, "Chemical constituents of Jatropha podagrica," Fitoterapia, vol. 69, no. 4, pp. 381-382, 1998.

[39] P. S. Sarin, D. Sun, A. Thornton, and W. E. G. Muller, "Inhibition of replication of the etiologic agent of acquired immune deficiency syndrome (human T-lymphocyte retrovirus/lymphadenopathy-associated virus) by avarol and avarone," Journal of the National Cancer Institute, vol. 78, no. 4, pp. 663-666, 1987.

[40] D. A. Scudiero, R. H. Shoemaker, K. D. Paull et al., "Evaluation of a soluble tetrazolium/formazan assay for cell growth and drug sensitivity in culture using human and other tumor cell lines," Cancer Research, vol. 48, no. 17, pp. 4827-4833, 1988.

[41] A. Aiello, M. D'Esposito, E. Fattorusso et al., "Novel bioactive bromopyrrole alkaloids from the Mediterranean sponge Axinella verrucosa," Bioorganic and Medicinal Chemistry, vol. 14, no. 1, pp. 17-24, 2006.

[42] W. E. G. Mueller, G. Seibert, and R. Beyer, "Effect of cordycepin on nucleic acid metabolism in L5178Y cells and on nucleic acid-synthesizing enzyme systems," Cancer Research, vol. 37, no. 10, pp. 3824-3833, 1977.

[43] G. Lauc, S. Perovic, J. Dapper, M. Flogel, S. Iskric, and W. E. G. Muller, "A non-radioactive, sensitive method for the detection of DNA fragmentation in apoptotic cells (rat pheochromocytoma PC12 and rat cortical cells)," Analytical Cellular Pathology, vol. 7, no. 2, pp. 107-114, 1994.

[44] G. Bringmann, G. Lang, J. Mühlbacher et al., "Sorbicillactone A, a structurally unprecedented bioactive novel-type alkaloid from a sponge-derived fungus," in Marine Molecular Biotechnology, W. E. G. Müller, Ed., pp. 231-253, Springer, Berlin, Germany, 2003.

[45] H. C. Schroder, P. S. Sarin, M. Rottmann et al., "Differential modulation of host cell and HIV gene expression by combinations of Avarol and AZT in vitro," Biochemical Pharmacology, vol. 37, no. 20, pp. 3947-3952, 1988.

[46] W. E. G. Muller, A. Maidhof, and R. K. Zahn, "Potent antileukemic activity of the novel cytostatic agent avarone and its analogues in vitro and in vivo," Cancer Research, vol. 45, no. 10, pp. 4822-4826, 1985.
[47] Z. Islam, C. C. Hegg, H. K. Bae, and J. J. Pestka, "Satratoxin Ginduced apoptosis in PC-12 neuronal cells is mediated by PKR and caspase independent," Toxicological Sciences, vol. 105, no. 1, pp. 142-152, 2008.

[48] O. O. Aiyelaagbe, K. Adesogan, O. Ekundayo, and J. B. Gloer, "Antibacterial diterpenoids from Jatropha podagrica Hook," Phytochemistry, vol. 68, no. 19, pp. 2420-2425, 2007.

[49] G. Schmeda-Hirschmann, F. Tsichritzis, and J. Jakupovic, "Diterpenes and a lignan from Jatropha grossidentata," Phytochemistry, vol. 31, no. 5, pp. 1731-1735, 1992.

[50] M. Spinella, "The importance of pharmacological synergy in psychoactive herbal medicines," Alternative Medicine Review, vol. 7, no. 2, pp. 130-137, 2002.

[51] K. S. Mitra and P. R. Rangesh, "Irritable colon (Grahni)," in Scientific Basis for Ayurvedic Therapies, L. C. Mishra, Ed., CRC Press, Boca Raton, Fla, USA, 2004. 


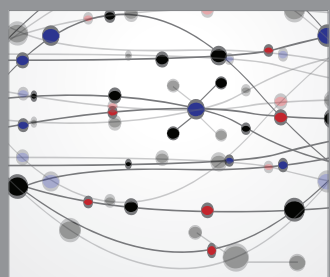

The Scientific World Journal
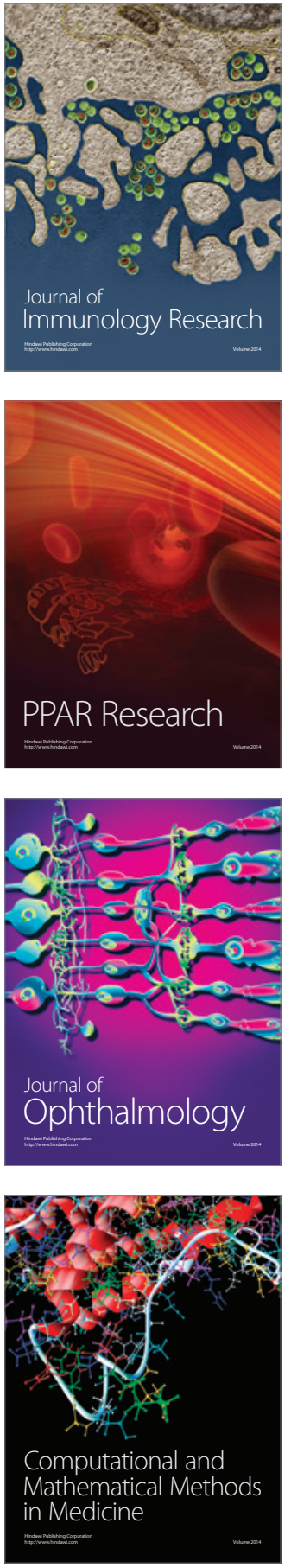

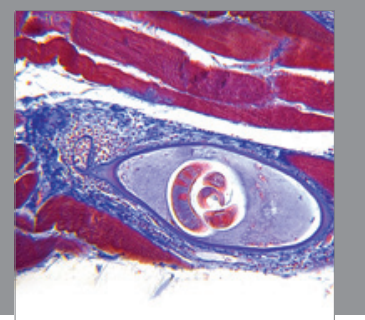

Gastroenterology

Research and Practice
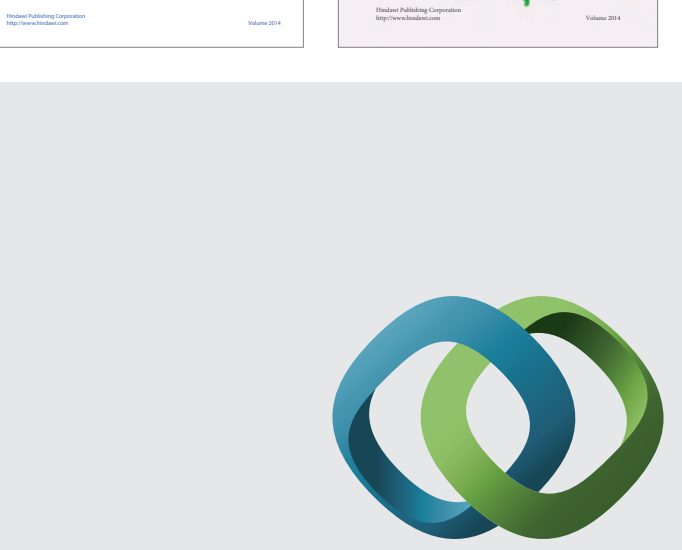

\section{Hindawi}

Submit your manuscripts at

http://www.hindawi.com
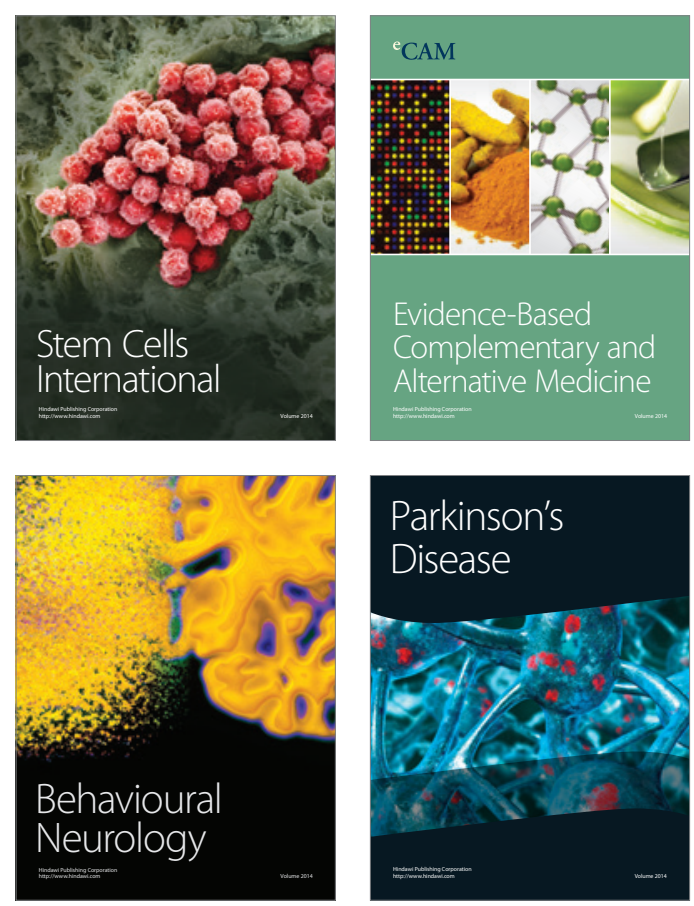

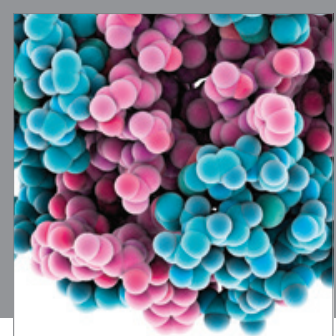

Journal of
Diabetes Research

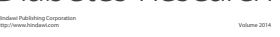

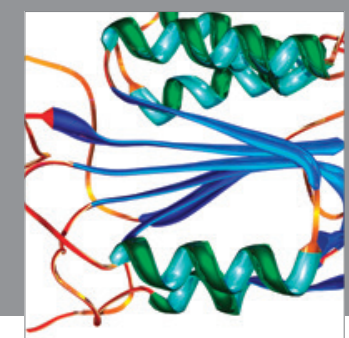

Disease Markers
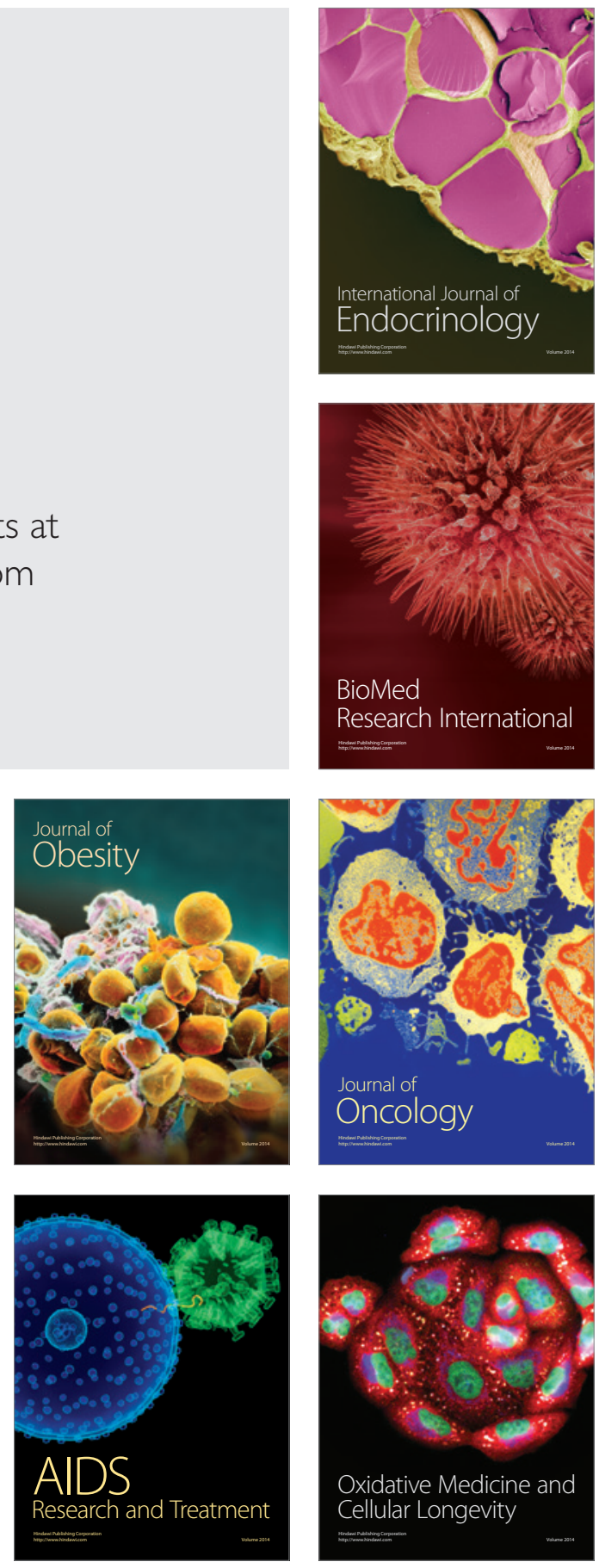